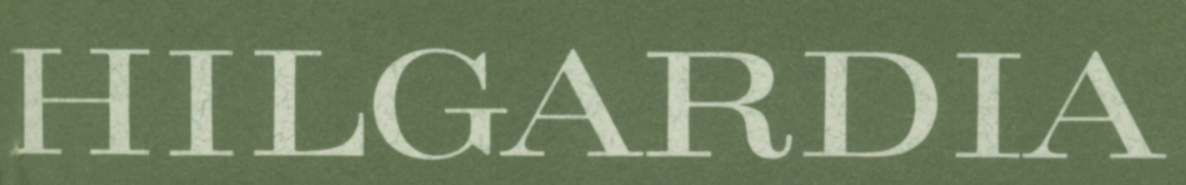

A JOURNAL OF AGRICULTURAL SCIENCE PUBLISHED BY THE CALIFORNIA AGRICULTURAL EXPERIMENT STATION

Volume 38, Number $11 \cdot$ October, 1967

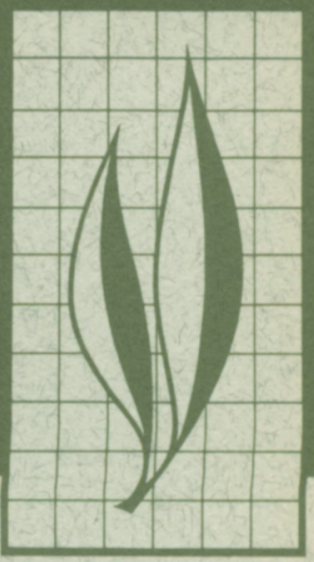

\title{
Grapevine Leafroll Virus-History and Anatomic Effects
}

L. L. Hoefert and E. M. Gifford, Jr. 


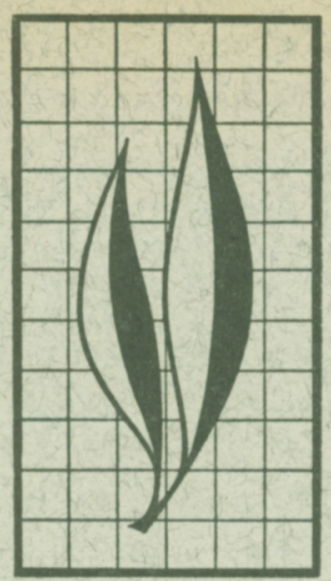

\section{CONTENTS}

History of the disease . . . . . . . . . . . . 403

Anatomic effects of the virus and its relationships to external

symptoms, environment, and nutrition . . . . . . 407

Introduction and literature review . . . . . . . . . 407

Materials and methods . . . . . . . . . . . 409

Results . . . . . . . . . . . . . . . 410

Anatomical symptoms in differentiating primary tissues. 410

Other symptoms . . . . . . . . . . . . . . 412

Distribution of symptoms in grapevines . . . . . . 412

Secondary symptoms . . . . . . . . . . . . . 412

Starch accumulation . . . . . . . . . . . 417

Leafroll and potassium deficiency . . . . . . . . . 417

Discussion . . . . . . . . . . . . . . . 417

Phloem degeneration . . . . . . . . . . . . . 417

Diversity of symptoms . . . . . . . . . . . . 418

Development and distribution of symptoms . . . . . 418

Secondary symptoms . . . . . . . . . . . . . 420

Starch accumulation . . . . . . . . . . . . . 421

Leafroll and potassium deficiency . . . . . . . . . . . 421

Summary . . . . . . . . . . . . . . . 421

Acknowledgments . . . . . . . . . . . . . . 421

Literature cited . . . . . . . . . . . . . . . . 422

\section{THE AUTHORS:}

L. L. Hoefert, formerly research assistant and technician, Department of Botany, University of California, Davis, is presently with the Crops Research Laboratory, Utah State University, Logan, Utah. E. M. Gifford, Jr., is Professor and Chairman, Department of Botany and Botanist in the Experiment Station, University of California, Davis. 


\section{Grapevine Leafroll Virus-History and Anatomic Effects ${ }^{1}$}

\section{HISTORY OF THE DISEASE}

LEAFROLL OF GRAPEVINE has been recognized as a disease for more than a century, but the first indication of its viral nature was given by Scheu (1936) ${ }^{2}$ when the disease was shown to be seed and graft transmitted. In California, Harmon and Snyder (1946) described a disease with symptoms of leafrolling that produced white berries in normally red-fruited grapevines of the variety Emperor. They accomplished graft transmission of the "white Emperor" disease to healthy grapevines. White Emperor was later proved identical to leafroll diseases of Germany and France, all of which were recognized as viral in origin (Goheen, et al., 1958; Vuittenez, 1958).

\section{Early descriptions of the disease}

Leafroll is known by several names in the French literature; early stages are referred to as "rougeau or flavescence" (Vidal, 1943) and later stages are termed "brunissure" (Cook and Goheen, 1961).

Rougeau (or red plague) was a term applied by early French viticulturists to a disease of the leaves described as occurring "in the summer owing to hot south winds after a fog." This description of the disease was included in Thiebaut de Berneaud's book, The Vine- dresser's Theoretical and Practical Manual, translated from the second edition by Felix Pascalis, M.D., in 1829. The appearance of rougeau was described as sudden, with a reddening of the leaves which fell within 2 days; fruits became wrinkled and dry. It is problematical whether this condition would be called leafroll today. Reddening of the leaves is a valid symptom but the disease generally progresses much more slowly.

The next description of leafroll is attributed to Fabre, 1853, who observed that the leaves turned remarkably red and slowly became wholly or partially desiccated. Fabre recognized that the disease appeared each year and was transmitted from one vine to another, but he associated no specific parasite with transmission of the disease and concluded that its nature was a mystery (Ravaz and Verge, 1924). Louis Leclere (1853) stated:

"I have seen this Rouge or Rouget in Languedoc, where it has been little known until now; it is acknowledged to have contributed a large part to the disaster of this year. Rouge has been observed more frequently in Bourgogne. People completely ignore this malady which attacks the leaf with a beautiful red color and paralyzes its functions."

\footnotetext{
${ }^{1}$ Submitted for publication January 6, 1967. This work formed part of a thesis submitted September, 1965, to the Graduate Division, University of California, Davis, by the senior author in partial fulfillment of the requirements for the degree of Doctor of Philosophy in Botany.

2 See "Literature Cited" for publications referred to in the text by author and date.
} 
Symptoms of leafroll have been described disparately over the years, probably as a result of varying varietal and environmental conditions. According to Goheen et al. (1958), symptoms progress from premature coloration and downward rolling of leaf margins on old leaves to the same effect on younger leaves, which become brittle and rugose. Interveinal chlorosis is often apparent and necrotic spots may develop to form large areas having a burned appearance. The disease tends to weaken the vines and causes a general reduction in yields, sometimes to an alarming degree.

\section{Organisms associated with the disease}

Although leafroll was at first attributed to unfavorable environmental conditions, later investigators found various insects and fungi associated with the disease. Pastre (1891) ascribed leafroll to the action of a scale insect, but some doubt was cast upon this when Mayet found an analogous scale insect on the variety Aramon in the absence of any leafroll symptoms (cited by Ravaz, 1904). Viala and Sauvageau (1892) described the causal organism as a parasitic myxomycete which they named Plasmodiophora vitis. Its taxonomic position in the Plasmodiophoraceae was questioned by Debray (1894) on the basis of exogenous spore formation; he later proposed the name Pseudocommis vitis (1895). Viala (1895) discussed a discovery of Brizi's which he considered to be particularly significant-the finding of a plasmodium in leafroll-infected cells. Brizi regarded the organism as a protozoan of unknown affinity (as cited by Viala, 1895). Moritz and Busse (1894) concurred with Viala and Sauvageau that Plasmodiophora vitis was the incitant of leafroll in Germany.

These observations were substantially negated by the work of Woods (1899), who applied the same technique, that of treatment of sections with Eau de Ja- velle, to healthy and infected cells of Vitis, and to cells of Lilium, tobacco, tomato, rose, hyacinth, and Spirogyra. He saw "plasmodes" or plasmodium-like structures in all cells treated and concluded that Plasmodiophora vitis and Pseudocommis vitis were artifacts. $\mathrm{He}$ attributed the artifacts to micro-chemical oxidations under alkaline conditions which caused coagulation of proteins, especially chloroplasts.

The Chytridiaceae were implicated as incitants of leafroll when Prunet (1894) proposed that a number of known diseases, including brunissure and maladie pectique, among others, were caused by Cladochytrium viticolum. Prunet's classification gained little favor, nor did that of Dufour (1902) who suggested that a larval form of the Erinose mite (Phytopus vitis) was responsible for the symptoms commonly called brunissure.

Various other fungi were thought to cause leafroll; many of these - e.g., Pseudopeziza tracheiphilla (MullerThurgau, 1915; Fäes, 1916; Osterwalder, 1922) and Exobasidium vitis (Prilleux and Delacroix, 1895) - are known today to cause other grapevine diseases.

\section{Occurrence and spread of the disease}

Leafroll was quiescent in Europe in 1893 but reappeared with severity in 1894 (Mazade, 1894; Guillon, 1894; and G. de M., 1894). Guillon remarked on the "lamentable aspect" of a vineyard situated in a large valley at Nizas. The vines, variety Aramon, were desiccated completely and were heavy with immature fruit. Similar defoliation symptoms later were described as mite damage (Jacob, et al., 1941) so uncertainty exists regarding the cause of the symptoms reported by Guillon. Diseased grapevines were reported in France, the Orient, Spain, Italy, Portugal, and Hungary (Guillon, 1895). Since then leafroll has been found in Germany 
(Scheu, 1936), South Africa (DuPlessis, 1950), California (Goheen et al., 1958), Washington State (Goheen et al., 1960), Australia (Fraser, 1961), and New Zealand (McKissock, 1964).

Leafroll was so common in some varieties that varietal descriptions referred to rolled leaves and early autumnal coloration (Ollram, 1938). White Gutadel and Early White Gutadel are notable examples (Goethe, 1878) now known to be particularly susceptible to infection by the leafroll virus.

\section{Environmental causes of the disease}

Some authors failed to credit the microorganism hypotheses and ascribed leafroll to environmental conditions (Cavara, 1894). Ducomet (1899) believed that humidity favored disease development and that large variations in temperature were likewise responsible. Ravaz (1902) noted that overproduction often accompanied leafroll symptoms, especially on weak vines. Others regarded overproduction as a likely cause of leafroll (Ducomet, 1904; Bioletti, 1909; Branas, 1929; Bonnet, 1937; Mauro, 1947). Butler (1905) and Parmentier (1947) held that disturbed water relations were the cause of leafroll. Root trouble and unfavorable weather were suspected as being at fault by Ravaz and Verge (1924). Ravaz (1925) added that soil conditions might prevent grapevines from consuming adequate nutrients and thus cause leafroll. The disease was observed most frequently in areas of heavy, compact subsoil; proper cultivation, fertilization, and irrigation were recommended to improve the soil and eliminate the disease (Soursac, 1924). Arnaud (1912) and Terrier and Staehelin (1953) held that excess insolation and transpiration were responsible for leafroll.

\section{Nutrient deficiencies and leafroll}

Zacharewicz (1900) was the first author to implicate nutrient deficiency in connection with leafroll when he described reduction in severity of the disease after application of potassium, lime, gypsum, nitrogen, and iron. Ravaz and Sicard (1903) analysed shoots, leaves, fruits, and roots of healthy and infected vines and found diseased leaves higher in nitrogen, magnesium, and calcium but substantially (50 per cent) lower in potassium. Ravaz and Roos (1905) reported that calcium was deficient in leafroll-infected grapevines. Control of leafroll with potassium fertilizers was advocated by Zacharewicz (1929) who postulated that the disease was physiological and similar to chlorosis in that recovery from leafroll was possible with potassium fertilization, just as iron application controlled chlorosis. A detailed study of potassium deficiency in leafroll infected vines showed that application of one kilogram of potassium sulfate per vine counteracted the symptoms of leafroll (Ravaz et al., 1933). Herschler (1936) classified leafroll as a nutritional disturbance due to potassium deficiency and suggested soil analyses for identification of the malady. Similarly, potassium deficiency was regarded as the cause of leafroll by Wilhelm (1938) and Vidal (1943). Maume and Dulac (1945) added that nitrogen and phosphorus could not substitute for potassium in control of leafroll. However, Stellwaag (1949) was not able to control symptoms of leafroll with potassium fertilization, and he concluded that the disease was of unknown cause. Wilhelm (1950) and Lafon et al., (1955) described brunissure, rougeau, and flavescence as potash-deficiency disorders.

The true nature of the association between leafroll and potassium deficiency remained obscure until Goheen and Cook (1959) discovered that potassium deficiency found in vine leaves infected with leafroll virus was a symptom of the disease rather than the cause. Leafroll and potassium deficiency were distinguished easily where soil potash was 
high but where soil potash was low, the two disorders were almost indistinguishable. Leaf blades and petioles were analysed throughout the season and results showed that the leafroll virus upset the normal distribution of potassium between petiole and blade and altered the levels of calcium and magnesium. Similar studies by Millikan et al., (1963) prompted the conclusion that the leafroll virus may interfere with protein synthesis as well as nutrient interactions.

\section{Discovery of virus nature}

Scheu (1936) described leafroll as a virus disease capable of transmission through budding and grafting but not through sap inoculation. Martinoff (1934) first mentioned that leafroll was a virus disease when he relegated many diseases (mal nero, court noué, reisigkrankheit, rougeau, brunissure, apoplexie, and others) to a general virus condition that evoked different symptoms in different varieties or under diverse environmental conditions.

In a joint publication by Stellwaag and Branas (1938), leafroll was considered as viral in nature because transmission by budding was possible. Branas (1939) indicated that leafroll might be flavescence, even though he later decided that leafroll and rougeau were probably not related-he suspected that leafroll was not a unique disease but a manifestation of some other virus disease, i.e., fanleaf. Later Olmo and Rizzi (1943) described a condition in grapevines of the variety Emperor in California that caused failure of the berries to achieve normal red color at harvest time. The disorder appeared in the progeny of the vines as well. Transmission studies by Hewitt (1952) indicated that the disease could pass through rootstocks into healty scions and there produce characteristic symptoms. In 1954 Hewitt reported that in addition to white fruit color in the variety Emperor, infected vines displayed distinct leafrolling and interveinal scorching of the leaves. Vines showing similar symptoms at the Horticultural Field Station at Fresno were selected for graft transmission tests by Harmon and Weinberger (1956). White fruit color was produced in the variety Emperor through grafts from all 32 vinifera varieties tested. In the same year, Cardinal and Red Malaga varieties were infected experimentally with the white Emperor virus and evidenced similar white fruit symptoms (Harmon, 1956).

Through symptomatology, California leafroll (white Emperor disease) was identified with rougeau, flavescence, brunissure, and German leafroll (Goheen et al., 1958). This was substantiated by Vuittenez (1958) through transmission studies which proved that a graft-transmissible agent was responsible for symptoms of a disease known previously as rougeau, flavescence, or brunissure.

A faster means of indexing for the presence of leafroll viruus was found by Goheen et al., (1959). The variety Mission was bud-inoculated with leafroll virus and produced foliage symptoms in 4 to 6 months. Previous experiments with Emperor vines as indicators required 3 or 4 years for the cuttings to bear and thus show white fruit symptoms of leafroll. Goheen and Hewitt (1964) have reported another indicator for leafroll virus, i.e., the use of Baco $22 \mathrm{~A}$ variety in which severe dwarfing and leaf epinasty occur during the span of one growing season. The authors have expressed the hope that the search will continue for other hosts of the leafroll virus. The importance of new hosts to research on plant virus diseases has been discussed by Kunkel (1943a).

Ochs (1959) concluded from graft transmission tests, that leafroll was a virus disease. She reported isolation of the virus from expressed juice of leafroll-infected stems and leaves and presented evidence that the causal agent was a bolt-shaped cylindrical virus 
$795 \AA$ in length. However, transmission of this virus by means of expressed sap was not possible, and therefore the validity of Och's work is questionable because infectivity of the isolated particles was not established. Thirty-five of the ninety-five stocks examined by Ochs were infected with leafroll virus in a latent condition. Many American rootstock varieties earry the virus but show no symptoms (Goheen and Hewitt, 1964).

\section{ANATOMIC EFFECTS OF THE VIRUS AND ITS RELATIONSHIPS TO EXTERNAL SYMPTOMS, ENVIRONMENT, AND NUTRITION}

\section{Introduction and literature review}

Early anatomical investigations on leafroll of the grapevine (Ravaz, 1904) demonstrated that starch differences existed in healthy and infected roots and that smaller nuclei were present in diseased cells. Ravaz and Verge (1924) observed phloem degeneration in connection with the disease: phloem cells underwent collapse in a centripetal direction from the region of pericyclic fibers (primary phloem fibers) toward the immature phloem. Few alterations were found in canes, aside from a reduction in the number and extent of phloem fibers. In younger shoots phloem degeneration similar to that found in leaf veins, accompanied by collapse of cortical cells or alterations in the medullary rays of the phloem and xylem, was observed.

Other virus diseases produce breakdown of the phloem tissue in which (Esau, 1948c): "a) degeneration begins with a necrosis of sieve tubes themselves and is or is not followed by pronounced growth disturbances (e.g., leafroll disease of potato, buckskin disease of peach and cherry, quick decline of citrus) ; b) degeneration begins with abnormal growth followed by more or less extended necrosis of the tissue resulting from this growth (e.g., curly-top disease of beet, bunchy-top disease of banana); c) degeneration consists of a rather generalized necrosis affecting various phloem cells and often involvings cells outside the phloem (e.g., black- root disease of snap beans; chlorotic streak disease of sugar cane)."

Leafroll disease of grapevine is notably similar to leafroll disease of potato. Even externally some resemblances are seen: e.g., rolling of leaves (although in potato leafroll the leaves roll adaxially), and accumulation of starch in lower leaves accompanied by abnormal turgidity of cells resulting in brittle leaves (Whitehead et al., 1953).

Phloem abnormalities associated with potato leafroll have received considerable attention (Esau, 1938). Quanjer (1913) was the first to report phloem necrosis, which he considered the cause of the disease. Degeneration of sieve tubes and companion cells was seen in leaves, petioles, and stems. The effects were not present in the seedling until after the first leaves had expanded, at which stage no external symptoms were apparent.

Later, Quanjer (1916) noted that the internal symptoms became more pronounced in the second year of infection. Collapse of sieve tubes and companion cells was accompanied by a swelling of the walls at junction points, and the deposition of a yellowish-brown substance in lumina and walls of infected cells (Quanjer, 1913). Artschwager (1918) confirmed these observations but described a separation of walls concomitant with the thickening. Bawden(1932) noted the formation of small intercellular spaces that became filled with a yellow deposit; only a small number of the phloem strands were necrotic and he 
found it difficult to agree with Quanjer that nonconduction was the cause of leafrolling.

Murphy (1923) proposed that accumulation of starch was responsible for rolling in infected leaves and that the plant eventually died of starvation because starch accumulation precluded further photosynthesis. Disturbances in the leaf and starch accumulation were regarded as the primary effect of the disease; phloem necrosis in the stem was a secondary effect. Natti (1955) found that starch grains from healthy plants swelled more in strong acid than did those from infected plants. $\mathrm{He}$ concluded that starch was structurally modified in diseased plants and that the modification interfered with enzymatic conversion of starch to sugar, resulting in abnormal accumulation of starch characteristic of leafroll virus infection in potato.

The yellow deposit previously referred to is probably a substance similar to wound gum (Esau, 1938). Analogous substances have been described by Magee (1939) in the phloem of banana infected with bunchy-top virus, in the phloem necrosis disease of elm (McLean, 1944), and in the buckskin disease of peach and cherry (Schneider, 1945). Schneider identified the substance as wound gum (according to Hewitt's definition [1938]) on the basis of histochemical tests.

External symptoms of the virus disease, buckskin of peach and cherry, show some marked resemblances to those described for grapevine leafroll. In cherry, fruits often develop a leathery surface and fail to mature. Leaves turn bright orange to red at the basal portion of the lamina. Peach leaves exhibit rolling and yellowing with later death of irregular regions of the lamina. Fruit and leaves of infected branches are shed early in the summer (Schneider, 1945). Although these symptoms are probably more severe than those described for leafroll of the grapevine, some analogies are evident, e.g., leafrolling, immaturity of fruit, reddening of leaves, and necrosis of irregular regions of the lamina (abscission is not reported in the grapevine disease, however).

The most common symptom reported by Schneider (1945) for buckskin disease was necrosis of sieve tubes and companion cells. Some parenchyma cells in the cortex and phloem collapsed while others hypertrophied. Abnormal amounts of secondary phloem were produced in leaves and petioles, especially in regions where swollen veins were evident externally. Decreased thickness of nacre walls (Esau, 1939; Esau and Cheadle, 1958) in the sieve elements of swollen veins was also detected. An abnormal accumulation of callose was found on sieve plates. Symptoms corresponding to disease symptoms were produced by ringing or by grafts on incompatible rootstocks (Schneider, 1954).

Necrosis of cells in the phloem is common in citrus tristeza (Price, 1966) and in sugar beet yellows disease (Esau, $1960 a)$. Beet yellows virus induces the formation of inclusion bodies in the phloem tissue, especially in companion cells and phloem parenchyma, where inclusions show a characteristic relationship to the maturation of sieve elements (Esau, 1960b). Inclusions of beet yellows virus are composed of aggregations of virus particles (Esau et al., 1966).

Barley yellow dwarf virus produces phloem degeneration in several species of Gramineae (Esau, 1957). Primary internal symptoms of the disease are necrosis of sieve tube elements, companion cells, and neighboring phloem parenchyma cells. The first degeneration is related to the maturation of the first sieve element of a given vascular bundle.

Primary symptoms of yellow leafroll of peach in a differential host, celery, were found to progress in the same 
manner as those of barley yellow dwarf (Esau, 1958). Differential susceptibility to the virus (or uneven distribution) was noted in two sieve elements recently derived from a longitudinal division of a procambial cell, one of which was necrotic while the other was normal.

Thus the effects of beet yellows virus, barley yellow dwarf, and yellow leafroll of peach are similar to those of the viruses of buckskin disease and potato leafroll. Two other disorders that may bear some resemblances to those are phloem necrosis of tea (Bond, 1947) and the stripe disease of corn (Cook, 1936). In the pear decline disease, Schneider (1959) found sieve tube necrosis analogous to that observed in quick decline of citrus. Pear decline recently has been established as a virus disease transmissible by grafting (Shalla et al., 1964) which is transmitted in nature by the pear psylla (Jensen et al., 1964).

\section{Materials and methods}

Collections. Field collections were made of healthy and leafroll-infected grapevines (Vitis vinifera L.) from San Joaquin County, California. Original samplings were taken of the vines, and cuttings were rooted in sand in the greenhouse for later collection. The cuttings were transferred to UC mix soil (Baker, 1957) and fertilized weekly with $200 \mathrm{ml}$ of $2 \mathrm{X}$ Hoagland's solution. The greenhouse was fumigated periodically for mite control, and vines were dusted with flowers of sulfur whenever the first sign of mycelial growth of mildew (Uncinula necator (Schw.) Burr.) appeared.

During the second year it was deemed necessary to keep the vines in a condition of active growth (through controlled photoperiod) to insure similar growing conditions in the samples taken. The grapevines were then transferred to an area of controlled photoperiod and allowed to grow under 16 hours light in each 24-hour period. Clearcut symptoms of leafroll were always present on the lower leaves of canes under these conditions.

Original samplings included stem tips, leaves, internodes, cluster stems, and fruit pedicels of seven healthy and seven infected vines. Leaves and apices of the variety Zinfandel were collected from greenhouse vines at later dates $(7 / 21 / 64 ; 11 / 5 / 64)$.

An additonal collecton of leaves and petioles was made $(7 / 21 / 64)$ of healthy and leafroll-infected grapevines, variety Baco 22A, from the Plant Pathology vineyard at Davis.

Permanent slides were made of earlier collections as well. The varieties, sources, and collection dates of the vines were as follows (Cook, Gifford, and Goheen, unpublished data):

$\begin{array}{lcl}\text { Variety } & \text { Date } & \text { Source } \\ \text { Zinfandel } & 9 / 30 / 60 & \text { Lodi } \\ \text { Carignane } & 8 / 5 / 59 & \text { UCD Viticulture } \\ \text { Mission } & 1959 & \text { Sonoma County } \\ \text { Grenache } & 1959 & \text { Santa Clara Co. } \\ \text { Burger (severe) } & 1959 & \text { Napa County }\end{array}$

The Lodi source vines were indexed in 1958 and were known to be healthy (Goheen et al., 1959; Goheen and Cook, 1959; Cook and Goheen, 1961; Goheen, unpublished data). The other varieties, with the exception of Baco 22A (Goheen and Hewitt, 1964) and Mission (Goheen and Cook, 1959), were selected on the basis of leafroll symptoms in the field.

Sectioning and staining. All material was killed and fixed in chromic acidacetic acid-alcohol or formalin-acetic acid-alcohol, embedded in tissuemat, and sectioned at $10 \mu$. Blocks of woody material were soaked in 10 per cent glycerine in 70 per cent ethanol for a period of from 1 to 2 weeks to facilitate sectioning on the rotary microtome. The bulk of sectioned material was stained with tannic acid-ferric chloride-lacmoid. Sections of roots, shoot apices, and developing leaves were stained with hematoxylin-safranin-fast green. Vari- 
ous histochemical stains were used: (a) iodine-potassium iodide for starch, (b) I-KI and sulfuric acid and (c) zincchlor-iodide as cellulose tests, (d) periodic acid-Schiff's reagent for staining total carbohydrates (Jensen, 1962), (e) Pyronin $\mathrm{Y}$ for ribonucleic acid (Brachet, 1953), (f) phloroglucinol$\mathrm{HCl}$ for wound gum (Hewitt, 1938), and (g) two lipid stains, Sudan Black B and Sudan IV (Jensen, 1962).

Starch test. A starch test involved a modification of the method described by Whitehead et al. (1953) for diagnosis of potato leafroll. Shoots bearing leaves and leaves alone were severed from healthy and infected greenhouse vines, placed in plastic bags, and kept in the dark for 48 hours. These were killed in boiling chloral hydrate and stored in 50 per cent ethanol overnight. Pieces of leaves were sectioned in pith on the sliding microtome at $20 \mu$, mounted in I-KI and studied with transmitted and polarized light.

Another series of leaves from healthy and infected vines was held in the dark for 60 hours, treated with chloral hydrate, embedded in paraffin, and sectioned at $10 \mu$ on the rotary microtome. The slides were stained with I-KI and were used for photomicrography (fig. 6, A and B).

Leafroll and potassium deficiency. Among the 1959 and 1960 collections were leafroll-infected and healthy stems, leaves, and petioles that had been treated with additional potassium or from which potassium had been withheld (Cook, Gifford, and Goheen, unpublished data). These vines were of the variety Burger, grown in sand culture in the greenhouse according to the method described by Cook and Goheen (1961). Anatomical observations were made of sections of leaves, stems, and petioles of the following treatments: (a) leafroll plus potassium, (b) leafroll minus potassium, (c) healthy plus potassium, and (d) healthy minus potassium.

\section{Method of numbering leaves and} internodes. Because viticulturists commonly number internodes from the base of the plant, it is necessary to describe the method of numbering used in this study. The grapevine bears spirally arranged palmate leaves with tendrils opposite the leaves, except at each third leaf where the tendril is absent. The apical portion of the shoot possesses protective stipules that subtend the developing leaves. An elongating internode appears below the region covered by stipules; this internode was termed internode 1 or " 1 " in the collections and all other internodes and leaves were numbered from the internode one. Leaf 1 in figure 1 denotes the first leaf below internode one.

\section{Results}

Anatomical symptoms in differentiating primary tissues. In the apical portion of the grapevine shoot, symptoms first are discernible in an internode undergoing elongation ("i one," fig. 1). Collapsed protophloem elements are evident in abnormal central positions in small vascular bundles from the first internode of leafroll-infected grapevines (fig. 2,A,C). Normal protophloem obliteration is present at the outer periphery of the vascular bundles from infected vines, as it is in vascular bundles from the first internode of healthy vines (fig. 2,B). In this study the collapse of a cell or cells in an abnormal position is regarded as the first sign of a virus effect.

Symptoms of sieve-tube necrosis in the infected vine are relatively extensive in the fifth internode below the apex (fig. 2,D), while only normal protophloem obliteration is evident in the healthy fifth internode (fig. 2,E). Similar effects are seen in vascular bundles of successive internodes down the infected stem. The apparent extent of degeneration is less in the older internodes, even though the external 


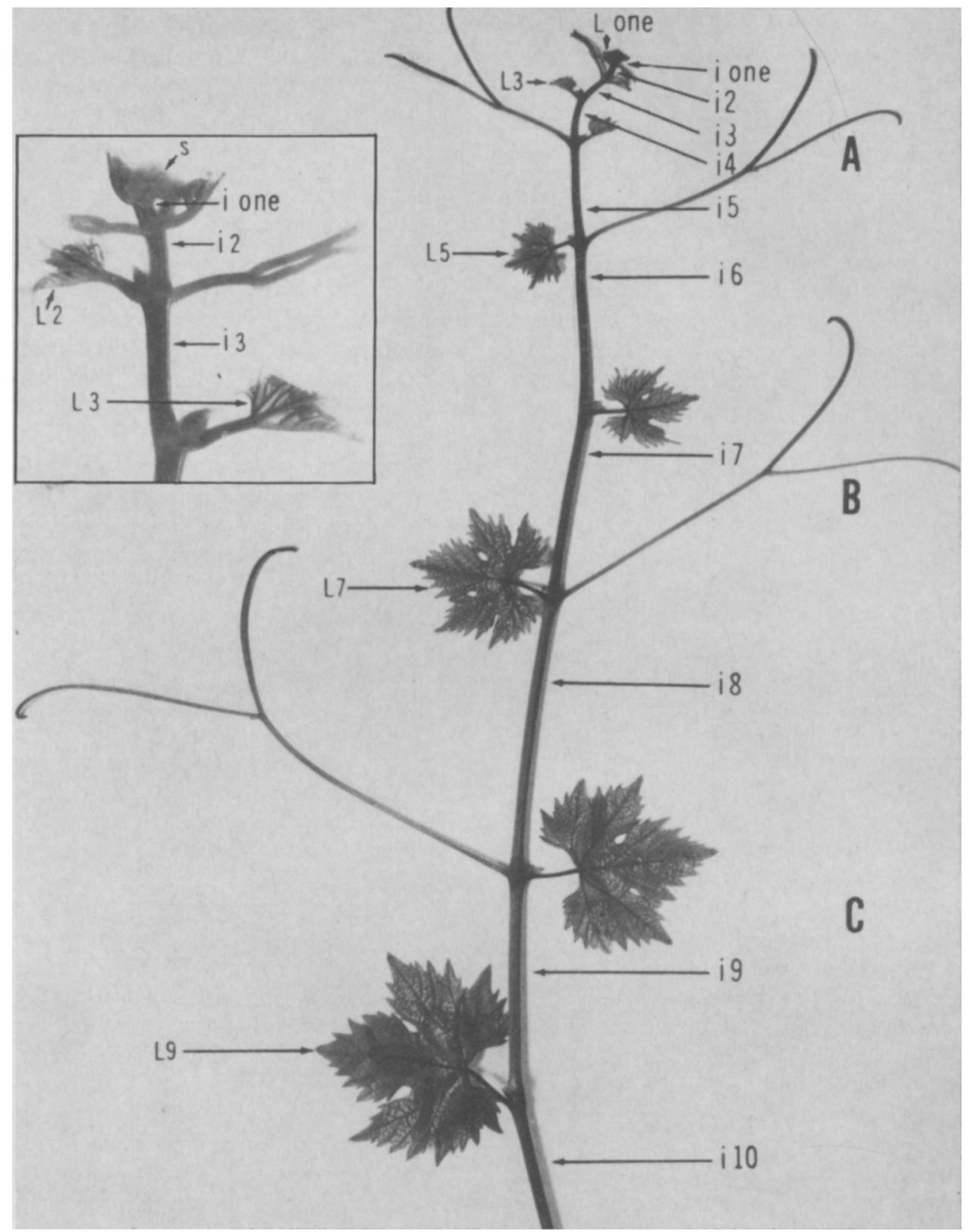

Fig. 1. Healthy grapevine shoot showing method of numbering of leaves (L one-L9 and internodes (i one-i 10). Apical region magnified (insert); stipules cover apex proper and several developing leaves. The first internode is the partially expanded internode below the level of attachment of the stipules. Leaf one is the first leaf below the internode one. A-C regions that correspond to regions of development of internal and external symptoms: A. Apical region of shoot; no external symptoms of leaf reddening or chlorosis; internal symptoms of phloem necrosis and degeneration develop here. B. Region of leaves 5 to 9 ; external symptoms of reddening and chlorosis develop here; anatomical symptoms relatively extensive. C. Region of mature leaves; external symptoms of leaf reddening striking; phloem degeneration extensive and often accompanied by hypertrophy, hyperplasia, and gumlike substance.

Details: L, leaf; i, internode; s, stipules. $(\times 2 / 5$; insert $\times 2)$ 
symptoms of leaf reddening become more pronounced.

Development of phloem necrosis in young leaves apparently parallels symptom development in the elongating internodes. The first sign of degeneration appears in the third or fourth leaf where no external symptoms of chlorosis or leaf reddening are present. The vascular tissue of the eighth leaf shows well-developed phloem degeneration, often accompanied by hypertrophy and hyperplasia of interfascicular parenchyma in the midvein and in the phloem parenchyma. Phloem degeneration present in vascular bundles of petioles of mature leaves (fig. 3,A) is not apparent in comparable healthy petioles (fig. 3,B). Pronounced degeneration occurs in vascular bundles from infected mature leaves (fig. 3,C), often accompanied by hypertrophy and hyperplasia (fig. 3, C and D; fig. 4, A and B). A gumlike deposit, that may represent dissolution of the middle lamella and deposition of yellow material between the cells, characteristically appears in vascular bundles of older infected leaves (fig. 4,C). Symptoms of phloem degeneration are present consistently in leaves, even in the lowermost ones collected from yearold canes of infected grapevines. This contrasts sharply with symptoms observed in canes of infected grapevines, where phloem degeneration was less in older internodes that had begun secondary growth than in younger primary tissues. Hypertrophy and hyperplasia were not observed in canes, nor was there any dissolution of wall material and/or deposition of gum.

Other symptoms: tyloses. Tyloses occur in the xylem elements of petioles of severely-affected vines of the variety Burger (fig. 4,D). Comparable healthy petioles exhibit no tyloses in the vessels of the xylem. Tyloses are formed by the ingrowth of adjacent parenchyma cells into vessels of the xylem through pitclosing membranes of pit-pairs (Esau,
$1948 b)$. In the new indicator variety for leafroll virus, Baco 22A (Goheen and Hewitt, 1964), tyloses occur in elements of the protoxylem and metaxylem in both leafroll-infected and healthy petioles. Tyloses normally are present in the grapevine, particularly in nonfunctioning xylem elements (Esau, 1948b).

Other symptoms: trabeculae. Trabeculae are present in stems and leaves of grapevines infected with leafroll virus. A treatment of this topic has been presented elsewhere (Hoefert and Gifford, 1967).

Distribution of symptoms in grapevines. Symptoms of phloem degeneration are found in stems, leaves, petioles, fruit pedicels, and cluster stems of leafroll-infected grapevines. Infected fruit pedicels (fig. 5, A) show severe phloem degeneration; the corresponding healthy ones do not (fig. 5, B). No symptoms are found in the shoot apex before the time of the first protophloem obliteration, nor do symptoms appear in mature canes. Root sections exhibit neither phloem degeneration nor other symptoms associated with leafroll virus infection.

Secondary symptoms. Secondary symptoms of the leafroll virus, or those alterations that occur after the first degenerative effects, include hypertrophy and hyperplasia. As noted earlier, these effects are present primarily in parenchyma tissue of leaves, either in interfascicular parenchyma (fig. 4, A) or in parenchyma rays in the phloem (fig. 4, B). Massive groups of cells may be formed through irregular divisions in all planes, accompanied by hypertrophy and crushing of the cells (fig. 4, B).

Another secondary symptom is the gumlike deposit occurring in leaves showing relatively advanced leaf reddening; this yellow substance is found in peripheral regions of the phloem tissue of vascular bundles of such leaves (fig. 4, C). Unlike the wound gum associated with potato leafroll disease 


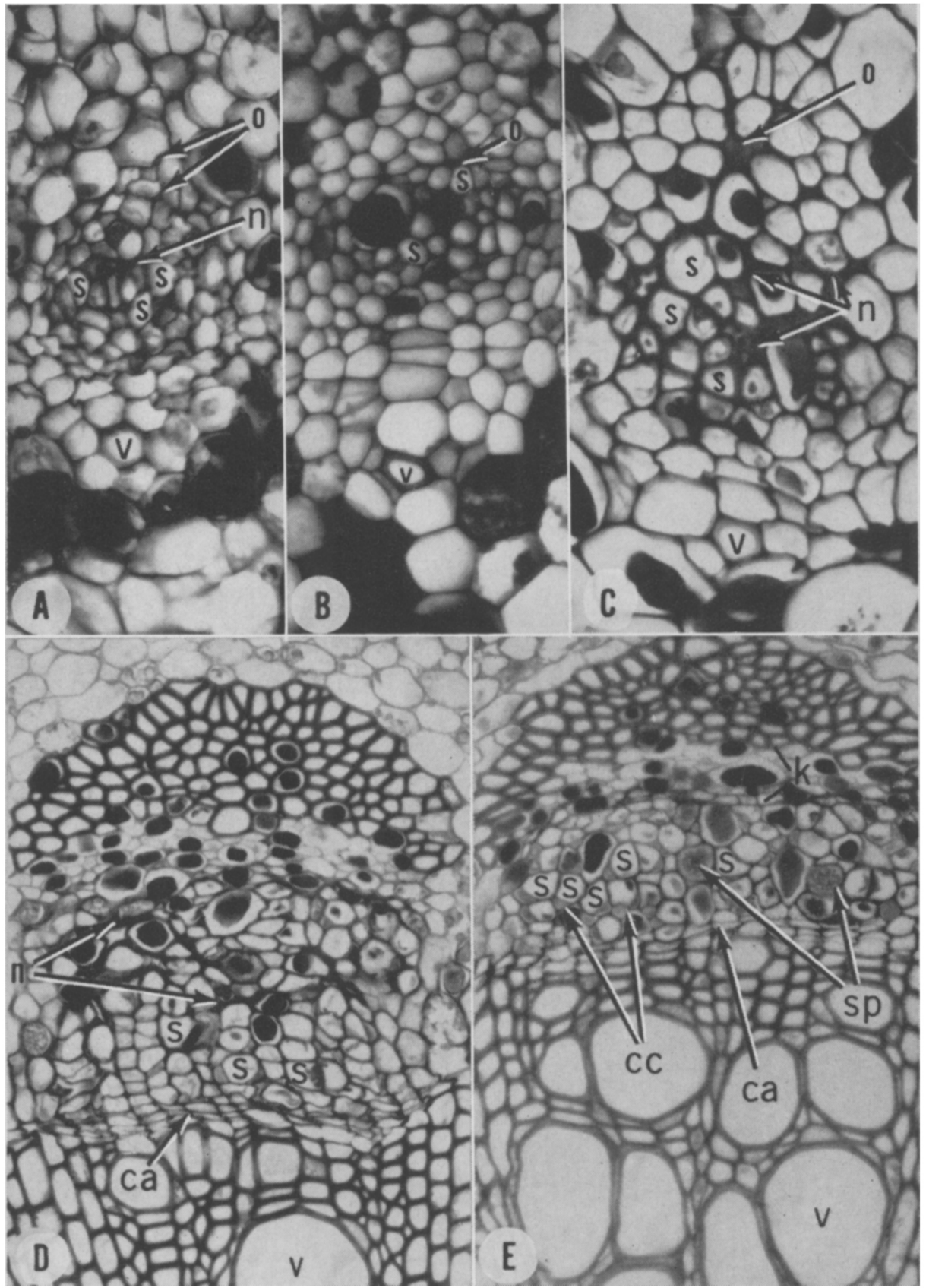

Fig. 2. Transverse sections of vascular bundles from internodes one (A,B,C) and five (D,E) of infected (A,C,D) and healthy (B,E) Zinfandel vines. A. Necrotic obliteration of sieve element in center of bundle $(n)$; normal protophloem obliteration at 0 ; primary vascular tissue present but no metaphloem differentiated. B. Vascular bundle, normal protophloem obliteration. C. Necrotic obliteration extensive; age of vascular strand approximates that of $A$ and $B$, judged by presence of a single protoxylem element. D. Vascular bundle, with secondary growth begun; necrotic cells in center of phloem tissue. E. Vascular bundle showing secondary growth and initial stages of periderm formation.

Details : ca, vascular cambium ; cc, companion cells; $k$, cork ; n, necrotic obliteration ; o, normal protophloem obliteration; $s$, sieve element; sp, sieve plate in transverse section; $v$, vessel elcments (or protoxylem elements). (A, E, ×400; B, ×440; C, ×660; D, ×350.) 


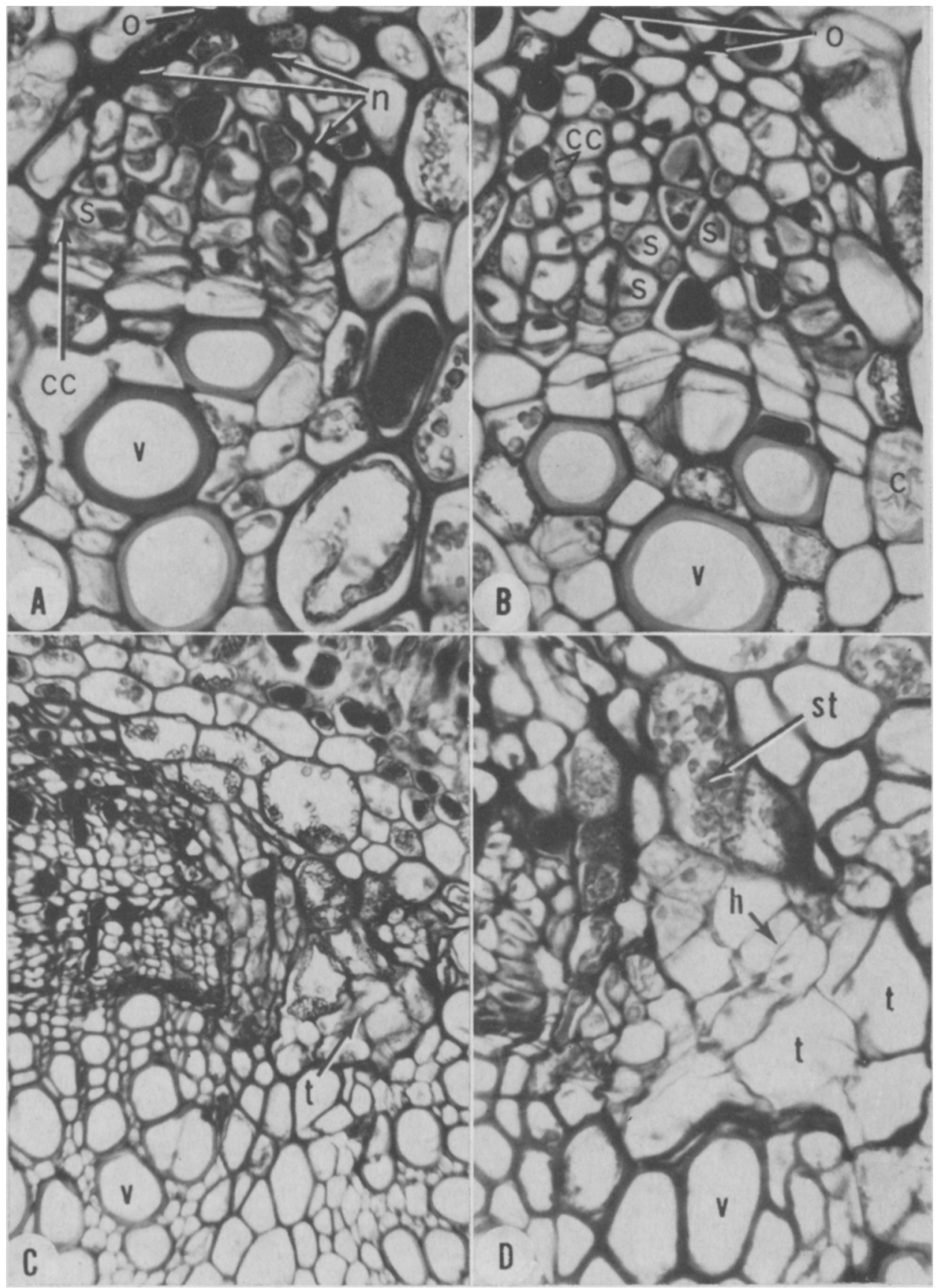

Fig. 3. Transverse sections of infected (A,C,D) and healthy (B) petioles (A,B) and leaf midveins (C,D), variety Zinfandel. A. Small vascular bundle; no secondary tissue present; necrotic cells at periphery of phloem. B. Comparable section to A; no necrotic obliteration evident; metaphloem sieve elements and companion cells present. C. Growth disturbances (hypertrophy) on right flank of vascular bundle in interfascicular parenchyma. D. Enlargement of interfascicular region showing hyperplastic and hypertrophied cells.

Details : c, oxalate crystal; cc, companion cell; h, hyperplastic cells; n, necrotic obliteration ; $o$, normal protophloem obliteration; s, sieve element; st, starch; t, hypertrophied cells; v, vessel elements of the xylem. (A,B,D, $\times 800 ; C, \times 400$.) 


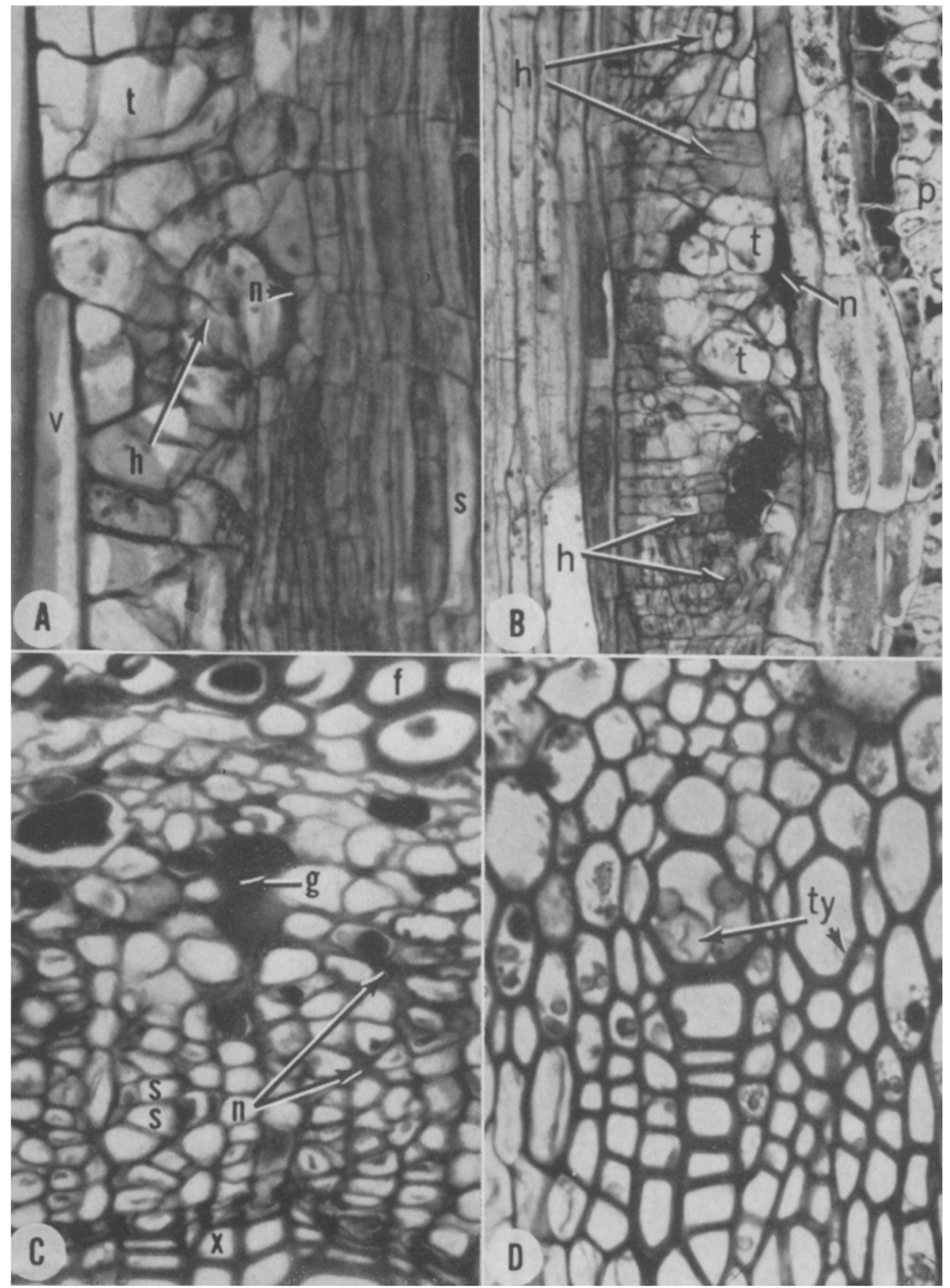

Fig. 4. Longitudinal (A,B) and transverse (C,D) sections of leafroll-infected leaves (A,B,C) and petiole $(\mathrm{D})$. A. Growth disturbances in parenchyma ray of phloem; xylem to left and phloem to right of the photo; dark substance in parenchyma cells is tannin. B. Hypertrophy and hyperplasia of phloem ray, accompanied by necrosis. C. Gumlike substance in vascular bundle of leaf midvein. D. Tyloses in xylem vessels of Burger vine.

Details: $f$, primary phloem fibers; $g$, gumlike substance; $h$, hyperplastic cells; $n$, necrotic cells; $p$, palisade tissue; $s$, sieve element; $t$, hypertrophied cells; ty, tyloses ; $v$, vessel element ; $\mathrm{x}$, parenchyma cell of xylem. $(\mathrm{A}, \times 360 ; \mathrm{B}, \times 200 ; \mathrm{C}, \times 625 ; \mathrm{D}, \times 700$.) 


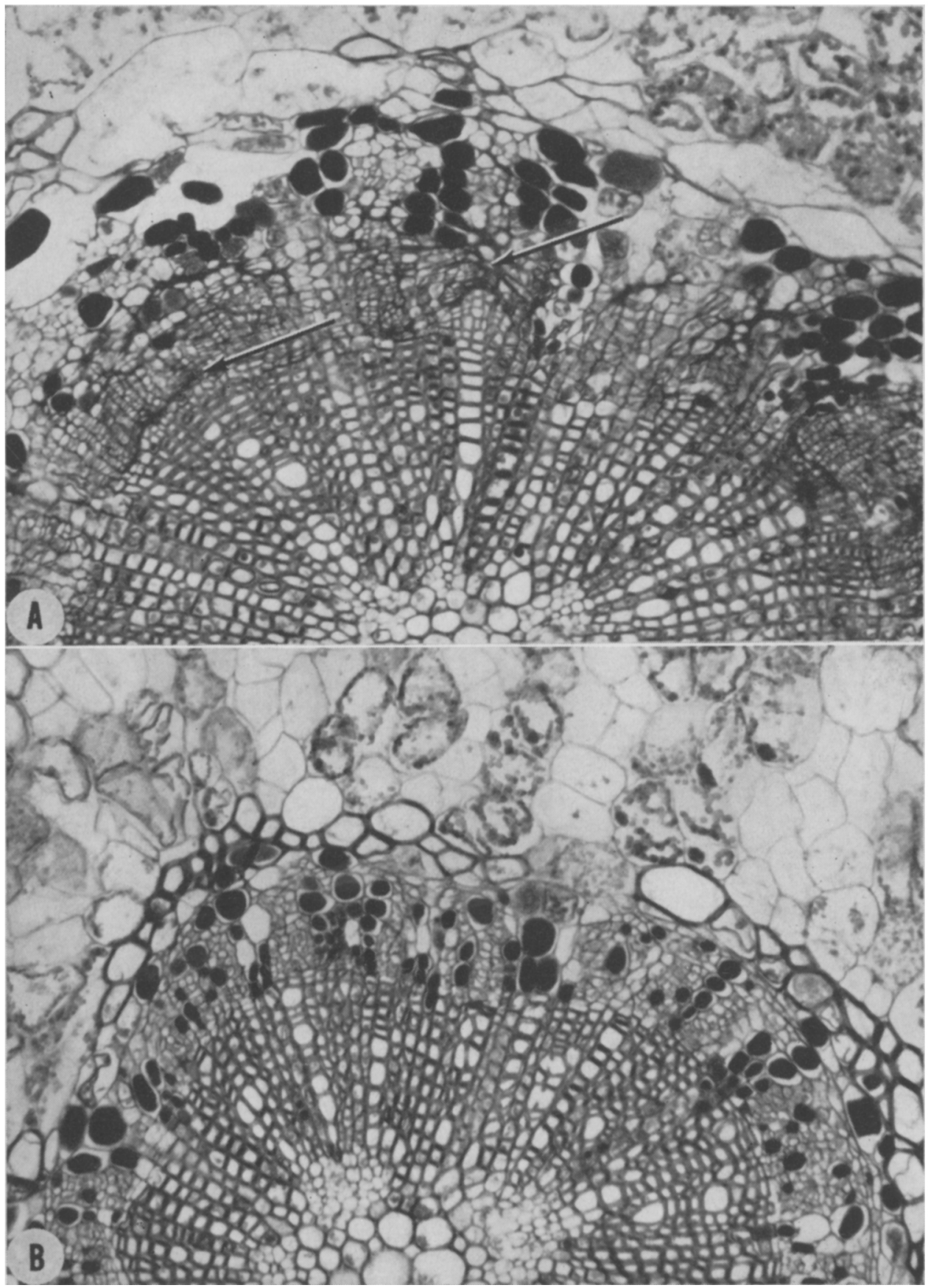

Fig. 5. Transverse sections of infected (A) and healthy (B) fruit pedicels, variety Zinfandel. Phloem degeneration indicated by arrows in $\mathrm{A}$ is not present in $\mathrm{B}$. $(\mathrm{A}, \times 320 ; \mathrm{B}, \times 330$.) 
(Sheffield, 1943) and the buckskin disease of peach and cherry (Schneider, 1945), the gumlike substance present in leaves infected with grapevine leafroll fails to stain with phloroglucinol$\mathrm{HCl}$, or with lipid stains. The substance may be a product of cellular degeneration deposited between cells that separate through dissolution of the middle lamella.

Starch accumulation. Infected and healthy leaves were kept in the dark for 48 hours, cleared, sectioned and stained with I-KI for starch. After the treatment, healthy leaf 1 (fig. 1) showed no starch reaction; leaves 2 to 6 contained starch only in guard cells, and leaves 7 to 9 possessed starch in the guard cells and a small amount in the starch sheath surrounding vascular bundles in the midvein. The infected leaf 1 gave no reaction; leaf 2 contained starch in guard cells, and leaf 3 showed starch in guard cells, starch sheath, and in an isolated region in the spongy parenchyma near the lower epidermis. At the level of the sixth expanded leaf from a leafroll-infected vine, starch remained in isolated areas of the spongy parenchyma, palisade tissue, guard cells, and in the starch sheath of midrib bundles in the green leaf tissue. External symptoms were apparent and the reddened areas were limited to the edges of the leaf and the leaf tip. After treatment the reddened regions were uniformly blue-black in stained sections, and all the cells (except the epidermal) contained much starch. Comparable amounts of starch were present in leaves 7 to 10 from infected grapevines. An infected leaf held for 60 hours in the dark exhibited a large quantity of starch (fig. 6,A) while the healthy leaf given the same treatment showed no starch reaction (fig. 6,B).

Thus, as we observed in development of internal symptoms in leaves, starch accumulation (which began to appear in infected leaf 3 ) also occurs before the advent of external symptoms of virus leafroll. Parmentier (1947) observed more starch accumulation in reddened areas of infected leaves than in green areas of the same leaves-an observation borne out by the present study.

Leafroll and potassium deficiency. Cook, Gifford, and Goheen (unpublished data) treated healthy and leafroll-infected grapevines of the variety Burger with both high and low potassium and collected material for anatomical observation. Through observation of a limited amount of material, the following facts come to view. Leafroll plus potassium (fig. 6,C) shows striking anatomical symptoms of phloem degeneration in petioles, stems, and leaf midveins of infected leaves accompanied by extensive hypertrophy and hyperplasia of phloem and interfascicular parenchyma. No aberrations could be detected in the comparable healthy material to which potassium had been applied (fig. 6,D). The vines from which potassium had been withheld also showed symptoms of phloem degeneration only in those infected with leafroll virus; potassium deficiency alone produced no anatomical changes. Results indicate that the effects of potassium on healthy vines cannot be detected anatomically; in addition, symptoms of leafroll are present whether the vines are given excess potassium or a limited supply. Thus, the anatomical symptoms of leafroll are not enhanced under a low-potassium regime nor are they decreased under high-potassium supply.

\section{Discussion}

Phloem degeneration. The extent of phloem degeneration symptoms reported here corroborates the findings of Ravaz and Verge (1924). The first degeneration in primary tissue superficially resembles normal protophloem obliteration in vascular bundles of young stems and leaves but either precedes it in time or degree. Because the 
first effects appear in the phloem tissue, grapevine leafroll may be classed with other diseases that produce primary effects on phloem tissue (Esau, 1938, 1948c). Hypertrophy and hyperplasia occur in leafroll leaves but they are undoubtedly a secondary or woundhealing response of tissue that has previously undergone degenerative changes.

Diversity of symptoms. The diversity of symptoms observed by early workers may be attributed to various inherent or external factors. Host varietal responses, or resistance and susceptibility, have received little attention, at least with regard to anatomical effects of virus diseases. This aspect would seem to warrant investigation, as varietal responses are the basis of plant breeding for resistance to many pathogens. External factors, notably influences of environment, play an important part in the expression of external symptoms of virus diseases (Bawden, 1964). Of paramount importance is the effect of masking of symptoms in the presence of elevated temperatures (Holmes, 1964). Elevated temperatures may even exert a curative influence in the case of certain virus diseases (Kunkel, 1943a). Other factors, such as the age of the organ at the time of infection or the particular strain of the virus, could have some bearing on the diversity of symptoms reported by early workers (Caldwell, 1934; Esau, 1935, 1938; Solberg and Bald, 1962). Different strains of the leafroll virus are thought to exist (Alley et al., 1963). Additionally many of the common rootstock varieties of the grapevine are symptomless carriers of the leafroll virus (Hewitt et al., 1962). A latent virus could produce changes that would relate to diversities in symptoms.

It is not difficult to imagine that anatomical symptoms could be as variable as external symptoms. Because no real comparative information is available, limited observations may serve to illus- trate this point. The Zinfandel material, upon which most of the study was concentrated, may prove to be intermediate in anatomical symptom-expression. Leaves of the variety Burger showed more severe anatomical symptoms than leaves of a comparable age from the Zinfandel stock. The variety Baco 22A, which exhibits pronounced growth disturbances, could prove to be the most striking in anatomical symptoms as well.

Because symptom-expression may differ in different varieties and under different environmental conditions, the work of Ravaz and Verge (1924) leaves some questions unanswered. No conditions of growth were outlined (no materials and methods were included) and the variety with which anatomical investigations were conducted was not specified. Additional confusion exists because the virus nature of leafroll was not known at that time and the authors considered the disease to be of physiological origin.

Development and distribution of symptoms. The development and distribution of anatomical sypmtoms associated with grapevine leafroll may provide some clues to the pathway of movement of the virus and to the effects of the incitant on the plant as a whole.

Because effects of the virus are seen in the phloem of developing primary tissues, it could be assumed that the virus moves in the phloem along with food materials that are being translocated to the sites of utilization of such materials (Bennett, 1940; Crafts, 1939; Esau, 1948c). Thus it would be expected that phloem degeneration would occur in developing roots as well. However, no anatomical symptoms were found in roots during this investigation, although Ravaz and Verge (1924) found degeneration in the roots of leafroll-infected grapevines. Age of roots could have had some bearing on the negative results obtained in this study 


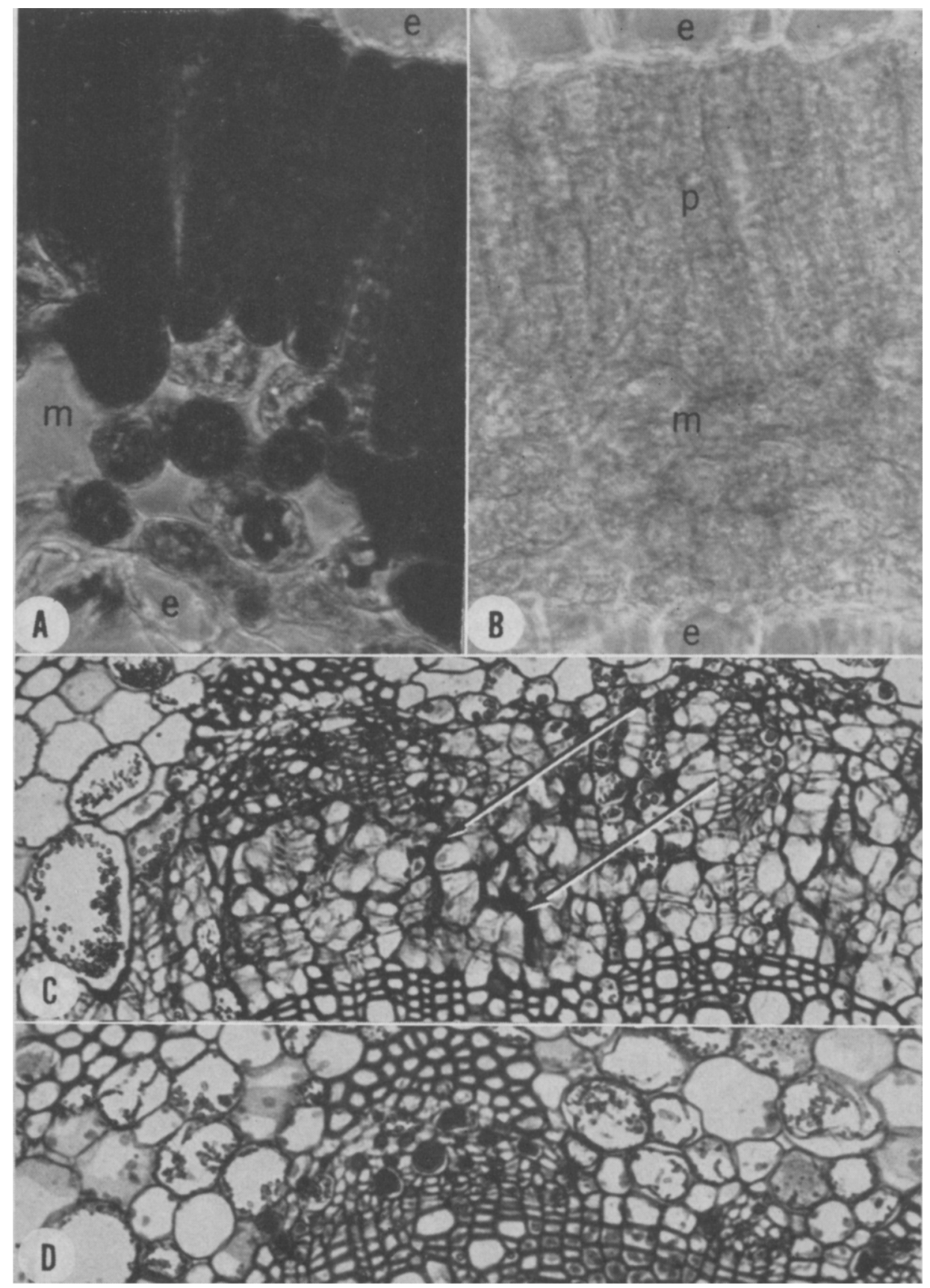

Fig. 6. Transverse sections of infected (A,C) and healthy (B,D) Zinfandel leaves (A,B) and Burger petioles (C,D). A. Mature leaf treated with I-KI after 60 hours in dark; excessive amounts of starch evidenced by black contents of palisade and spongy parenchyma. B. Healthy leaf of same age as A, treated similiarly; no starch reaction present. C. Leafroll plus potassium fertilizer; with phloem degeneration characteristic of leafroll. D. Healthy plus potassium fertilizer; no phloem degeneration is evident.

Details: e, epidermis; $\mathrm{m}$, mesophyll cells; $\mathrm{p}$, palisade parenchyma; arrows point to phloem necrosis. (A,B, $\times 600 ; \mathrm{C}, \times 350 ; \mathrm{D}, \times 380$.) 
but a symptomless condition of the virus could not have had any, because rooted cuttings of the scion (vinifera) variety were used for anatomical observations.

Phloem degeneration symptoms are present in vascular tissue that has undergone little secondary growth, but by the time secondary growth is advanced no anatomical aberrations are detectable in the stem. This confirms the observations of Ravaz and Verge (1924) who reported no symptoms in the phloem of mature canes except irregular lignification, which has been shown to be a normal feature of grapevine development (Esau, 1948a). An analogy may be drawn between leafroll of the grapevine and potato leafroll. Sheffield (1943) reported that phloem degeneration accompanying potato leafroll virus infection was restricted largely to primary phloem. The same statement could be made for grapevine leafroll virus infection, with the qualification that symptoms do appear in the early secondary phloem and in cells of the interfascicular regions after formation of a vascular cambium. One-yearold canes (i.e., canes with well-developed secondary tissue) show no anatomical aberrations. The significance of symptom-expression more or less restricted to the primary plant body remains obscure. However, it is proposed that primary tissue is more susceptible to attack by leafroll virus than is secondary tissue.

Secondary symptoms. Secondary symptoms of the leafroll virus in the grapevine are hypertrophy and hyperplasia. Similar growth disturbances have been described in a number of other virus diseases (Esau, 1938; 1948c). Sheffield (1943) regarded hypertrophy as a minor characteristic of potato leafroll disease. Schneider (1945) reported that severe cases of buckskin disease showed hypertrophy of all types of cells in the phloem tissue without a particular effect on paren- chyma cells alone, he maintained that hypertrophy might be due to abnormal cambial activity in the affected leaves. Secondary hypertrophy and hyperplasia were found by Esau (1957) in Gramineae infected with the barley yellow dwarf virus. There, the reactions were described as wound-healing responses of tissue that had undergone collapse or as independent secondary responses outside the collapsed tissue. Vigorous hyperplasia and some hypertrophy were seen in celery infected with peach yellow leafroll virus; these were considered to be secondary or wound-healing responses (Esau, 1958) -as were growth disturbances in cells in the present study.

In grapevine leafroll a gumlike formation accompanies cellular degeneration in some cases. Schneider (1945) found wound gum present in infected sieve tubes of buckskin-diseased peach and cherry. The substance indicated as gumlike in the present study did not strain with phloroglucinol- $\mathrm{HCl}$ and so was not identifiable as wound gum. It is thought to be a product of cell degeneration, and thus a secondary effect of leafroll disease.

The presence of tyloses in severely affected Burger petioles is also considered to be a secondary symptom of the leafroll virus disease of the grapevine. The absence of tyloses in the healthy material supports this conclusion. Because tyloses occur naturally in the grapevine (Esau, 1948b), their existence in leafroll-infected Burger vines does not preclude their presence in healthy Burger vines. Tyloses may occur in both infected and healthy Burger grapevines just as they do in the variety Baco $22 \mathrm{~A}$, but the fact that they were found in leafroll-infected material only (at the time of collection) indicates that at that particular stage of development tyloses could be a valid symptom of leafroll infection.

Tyloses commonly occur in healthy grapevines in the fall or winter and 
then only in no longer functional xylem elements (Esau, 1948b). The presence of tyloses in summer-collected material is premature, if nothing else. This indicates that degeneration and senescence are often accentuated by virus disease.

Starch accumulation. Starch accumulation in connection with grapevine leafroll was first recorded as a symptom by Ravaz and Roos (1905). Goheen and Schnathorst (1961) performed paper chromatographic sugar analyses on healthy and infected leaves and documented starch increase in leafroll-infected leaves. Glucose, fructose, and sucrose were present in healthy and infected leaves, but were much more concentrated in infected tissues.

The present investigation confirms the existence of accumulated starch in leafroll-infected leaves, and indicates that starch accumulation parallels the development of anatomical symptoms to a certain extent. It was not established whether starch accumulation actually precedes the first anatomical symptom of phloem degeneration, or whether degenerative effects come first. However, phloem degeneration could provide an impediment to translocation that would result in starch accumulation.

Leafroll and potassium deficiency. Cook and Goheen (1961) suggested that leafroll and potassium deficiency could be separated by leaf blade and petiole analyses, or by visual observation of symptoms when they first develop. They also noted that high potassium reduced external symptoms of leafroll but did not prevent their development, and that under a low potassium supply leafroll accentuated potassium-deficiency symptoms.

Limited anatomical observations of healthy and leafroll-infected grapevines that had been subjected to conditions of both high and low potassium lead to the following conclusions:

1. high potassium does not counteract the anatomical symptoms of leafroll;

2. low potassium does not enhance the anatomical symptoms of leafroll;

3. high and low levels of potassium cannot be detected anatomically in the healthy grapevine and,

4. potassium deficiency and leafroll could easily be distinguished on the basis of anatomical symptoms either in leaves showing external symptoms of the disorders or in petioles of the same leaves.

\section{SUMMARY}

Leafroll of grapevine is a virus disease characterized by premature reddening of leaves, starch accumulation, and reduced yields.

The primary anatomical effect of the virus is phloem degeneration in vascular bundles of leaves, stems, and fruit pedicels of affected grapevines. Phloem degeneration related to leafroll is typical of virus diseases associated with the phloem tissue but producing no initial growth disturbances. Degenerative effects are seen as crushing and oblitera- tion of sieve elements and occur in conjuction with maturation of sieve elements. Other internal symptoms are secondary hypertrophy and hyperplasia of phloem parenchyma, production of gum, and on occasion, formation of tyloses in the xylem elements.

Anatomical effects of phloem degeneration are seen in infected shoots, developing leaves, and fruit pedicels of leafroll-infected grapevines. Older canes possessing well-developed secondary tissue show few alterations.

\section{ACKNOWLEDGMENTS}

The authors acknowledge the efforts of Dr. William B. Hewitt, Dr. H. B. Currier, and Dr. A. C. Goheen who contributed time and counsel to this proj- ect. Thanks are extended to Dr. Katherine Esau, University of California, Santa Barbara, for use of facilities in taking some of the photomicrographs. 


\section{LITERATURE CITED}

Alley, C. J., Goheen, A. C., Olmo, H. P., and Koyama, A. T.

1963. The effect of virus on vines, fruit, and wines of Ruby Cabernet. Amer. J. Enol. and Viticult. 14:164-70.

ARnAUd, J.

1912. Le soleil et les maladies physiologiques des végétaux. Progr. agr. et vit. 57:115-23.

ARTSCHWAGER, E. F.

1918. Histological studies on potato leafroll. J. Agr. Res. 15:559-70.

BAKER, K. F.

1957. The U. C. system for producing healthy container-grown plants. Univ. Calif., Div. Agr. Sci., Agr. Expt. Sta. Extension Service Manual 23. 332 pp.

BAWDEN, F. C.

1932. A study of the histological changes resulting from certain virus infections of the potato. Proc. Roy. Soc. London B. III:74-85.

1964. Plant Viruses and Virus Diseases. (4th ed.) New York: Ronald Press Co., 361 pp.

BENNETT, C. W.

1940. The relation of viruses to plant tissues. Bot. Rev. $6: 427-73$.

Berneaud, THIEBAUt DE

1829. The Vine-dresser's Theoretical and Practical Manual. (Translated from the 2nd ed. by Felix Pascalis.) New York: P. Cranfield, 158 pp.

BIOLETTI, F. T.

1909. Physiological diseases of the vine. Pacific Rural Press 78:5.

BOND, T. E.

1947. The "phloem necrosis" disease of tea of Ceylon. III. Further characteristics of necrosis in the leaf. Ann. Appl. Biol. 34:517-26.

BonNetT, A.

1937. La brunissure. Progr. agr. et vit. 92:373-76.

BRACHET, J.

1953. The use of basic dyes and ribonuclease for the cytochemical detection of ribonucleic acid. Quart. J. Microscop. Sci. 88:383-92.

Branas, J.

1939. Études effectueés sur le court-noué en France et en Allemagne et conclusions qu'elles permettent. Progr. agr. et vit. III:1-28.

BRANAS, M.

1929. La roussure des producteurs directs. Progr. agr. et vit. 92:372-76.

BUTLER, O.

1905. Observations on some vine diseases in Sonoma County, California. Calif. Agr. Expt. Sta.

Caldwell, J. Bul. 186. 29 pp.

1934. The physiology of virus diseases in plants. V. The movement of the virus agent in tobacco and tomato. Ann. Appl. Biol. $21: 191-205$.

Cavara, F.

1894. La brunissure de la vigne en Italie. Rev. Intern. de viticult. et di oenologie. 1:3-9.

COOK, J. A., and GOHeEN, A. C.

1961. The effect of a virus disease, leafroll, on the mineral composition of grape tissue and a comparison of leafroll and potassium deficiency symptoms. Amer. Inst. Biol. Sci.,

Сook, M. T. publ. no. 8, $1961: 338-54$.

1936. Phloem necrosis in the stripe disease of corn. J. Agr. Univ. Puerto Rico. $20: 685-88$.

CRAFTS, A. S.

1939. Movement of viruses, auxins, and chemical indicators in plants. Bot. Rev. 5:471-504.

DEBRAY, F.

1894. Nouvelles observations sur la brunissure. Rev. de viticult. $2: 152-55 ; 221-26$.

1895. La brunissure chez végétaux et en particulier dans la vigne. Rev. de viticult. 3:562-65; $614-19 ; 4: 16-18 ; 34-39 ; 61-64 ; 83-88 ; 293-95$.

DUCOMET, V.

1899. La brunissure de la vigne et ses causes. Progr. agr. et vit. 32:198-204.

1904. La brunissure des végétaux et sa signification physiologique. Compt. Rend. Assoc. pour l'Avance des Sci. 32:697-707.

DuFour, $\mathrm{J}$.

1902. La brunissure de la vigne. Progr. agr. et vit. 38:279-80. 
DuPlessis, S. J.

1950. Virus diseases and some symptomatologically related abnormalities of the vine. Ann. Univ. Stellenbosch 26A:1-33.

EsAU, K.

1935. Initial localization and subsequent spread of curly-top symptoms in the sugar beet. Hilgardia 9(8) :397-436.

1938. Some anatomical aspects of plant virus disease problems. Bot. Rev. 4:548-79.

1939. Development and structure of the phloem tissue. Bot. Rev. 5:373-432.

1948a. Phloem structure in the grapevine, and its seasonal changes. Hilgardia 18(5):217-96.

1948b. Anatomic effects of the viruses of Pierce's disease and phony peach. Hilgardia 18(12): 423-82.

1948c. Some anatomical aspects of plant virus disease problems. II. Bot. Rev. 14:413-49.

1957. Phloem degeneration in Gramineae affected by the barley yellow dwarf virus. Amer. J. Bot. 44 : 245-51.

1958. Phloem degeneration in celery infected with yellow leafroll virus of peach. Virology $6: 348-56$.

1960a. Cytologic and histologic symptoms of beet yellows. Virology 10:73-85.

$1960 \mathrm{~b}$. The development of inclusions in sugar beets infected with the beet-yellows virus. Virology 11:317-28.

Esau, K., and Cheadle, V. I.

1958. Wall thickening in sieve elements. Proc. Natl. Acad. Sci. 44:546-53.

Esau, K., Cronshaw, J., and Hoefert, L. L.

1966. Organization of beet yellow-virus inclusions in leaf cells of Beta. Proc. Natl. Acad. Sci. 55:486-93.

FÄES, H.

1916. L'affection de la vigne dite "Rougeau." Progr. agr. et vit. 66:444-48.

Fraser, L. R.

1961. Leafroll of grapevines in New South Wales. Commonwealth Mycol. Conf. Rpt. 6: 120-23.

GoETHE, $H$.

1878. Handbuch der Ampelographie. Graz. Commissions-Verlag von Leykam-Josefsthal. $280 \mathrm{pp}$.

Goheen, A. C., Clore, W. J., and Skotland, C. B.

1960. Survey for grape virus diseases in Washington. Wash. State Hort. Assoc. Proc. 56: 228-30.

Goheen, A. C., and Cook, J. A.

1959. Leafroll (red-leaf or rougeau) and its effects on vine growth, fruit quality and yields. Amer. J. Enol. and Viticult. 10:173-81.

Goheen, A. C., Harmon, F. N., and Weinberger, J. H.

1958. Leafroll (White Emperor Disease) of grapes in California. Phytopathology 48:51-54.

Goheen, A. C., HewitT, W. B., and Alley, C. J.

1959. Studies of grape leafroll in California. Amer. J. Enol. and Viticult. 10:78-84.

Goheen, A. C., and Hewits, W. B.

1964. Diagnosis of leafroll of grapevines. Riv. di Patol. Veg. 4:427-42.

Goheen, A. C., and Schnathorst, W. C.

1961. Resistance to powdery mildew in leafroll-affected grapevines. Plant Dis. Reporter 45: 641-43.

Guillon, J. M.

1894. Un cas extrêmement grave de brunissure. Rev. de viticult. 1894 (2) :338.

1895. Observations sur le développement de la brunissure. Rev. de viticult. 1895:420-21.

HARMON, F. N.

1956. White Emperor virus in Cardinal and Red Malaga grapes. Proc. Amer. Soc. Hort. Sci. $67: 302-03$.

HARMON, F. N., and SNYDER, E.

1946. Investigations on the occurrence, transmission, spread and effect of "white" fruit color in the Emperor grape. Proc. Amer. Soc. Hort. Sci. $47: 190-94$.

HARMON, F. N., and WeINBERGER, J. H.

1956. Foliage burn of vinifera grapes as a symptom of white Emperor disease. Plant Dis. Reporter 40:300-03.

\section{HERSCHLER, A.}

1936. Ernährungsstörungen an Reben durch Bodenverhältnisse mit besonderer Berücksichtigung von Kalimangelschäden. Ernahr. Pflanz. 32 :197-204. 
HEWITT, W. B.

1938. Leaf-scar infection in relation to the olive knot disease. Hilgardia $12(1): 41-71$.

1952. Transmission of the factor causing "white Emperor" through different grapestocks. Phytopathology 42:514. (abstr.).

1954. Some virus and virus-like diseases of grapevines. Calif. Dept. Agr. Bull. 43:47-64.

HewitT, W. B., Goheen, A. C., Raski, D. J., and Gooding, G. V., JR.

1962. Studies on virus diseases of the grapevine in California. Vitis 3:57-83.

HOEFERT, L. L., and GiFFord, E. M., JR.

1967. Trabeculae in the grapevine infected with leafroll virus. Amer. J. Bot. 54:257-61.

Holmes, F. O.

1964. Symptomatology of viral diseases in plants. In Plant Virology. Corbett and Sisler, eds., Gainesville, Florida: University of Florida Press, pp. 17-38.

JAcob, H. E., Hewitt, W. B., and Proebsting, E. L.

1941. Red leaf of grapevines in California prevented by controlling mites. Proc. Amer. Soc. Hort. Sci. 39:285-92.

Jensen, D. D., Griggs, W. H., Gonzales, C. Q., and Schneider, H.

1964. Pear psylla proved carrier of pear decline virus. Calif. Agr. 18:2-3.

Jensen, W. A.

1962. Botanical Histochemistry. San Francisco and London: Freeman and Co., $408 \mathrm{pp}$.

KUNKEL, L. O.

1943a. New hosts as a key to progress in plant virus disease research. In Virus Diseases. Rivers, Kunkel, Stanley, Shope, Horsfall, Rous, eds. Ithaca, New York: Cornell Univ. Press, $170 \mathrm{pp}$.

$1943 b$. Viruses in relation to growth of plants. Torreya 43:87-95.

Lafon, J., Chouillaud, P., and Hude, R.

1955. Maladies et Parasites de la Vigne. Libraire J.-B. Bailliere et Fils, Paris. 364 pp.

LECLERC, L.

1853. Les Vignes Malades. Librairie de L. Hachette et Cia., Paris. 80 pp.

M., G. DE

1894. Note sur la brunissure de la vigne. Rev. de viticult. 2 : 313-14.

Magee, C. J. P.

1939. Pathological changes in the phloem and neighboring tissues of the banana (Musa cavendishi lamb.) caused by the bunchy-top virus. Dept. Agr. New South Wales Sci. Bul. $67: 1939$.

MARTINOFF, S. I.

1934. Mosaic or reisigkrankheit of the vine. Rev. Appl. Mycol. 13:491-92 (Abstr.).

MAUme, L., and Dulac, J.

1945. Cavence potassium chez le vigne décelée par la côntrole chimique de la feuille avant l'apparition de la brunissure. Compt. Rend. Acad. Sci., Paris. $221: 116-18$.

MAURo, J.

1947. La brunissure. Le Vigneron Champenois 68:323-27.

MAZADE, M.

1894. La brunissure aux environs de Montpellier. Rev. de viticult. 1894 :282-83.

McKIssock, A.

1964. Two important virus diseases of grapevines in New Zealand. New Zeal. J. Agr. 108:4, 332-39.

MCLEAN, D. M.

1944. Histopathologic changes in the phloem of the American elm affected with the virus causing phloem necrosis. Phytopathology 34:818-26.

Millikan, D. F., Pickett, E. E., and Hemphill, D. D.

1963. Some preliminary observations on the potassium, magnesium, and protein content of grape tissue associated with leafroll. Plant Dis. Reporter 47:213-15.

Moritz, J., and Busse, W.

1894. Über das Auftreten von Plasmodiophora vitis in deutschen Weinbaugebeite. Z. Pflanzenkrank. $4: 257$.

Muller-Thurgau, $\mathrm{H}$.

1915. Zur Bekämpfung des roten Brenners der Reben durch Bespritzungen mit Bordeauxfrühe. Landwirt. Jahrb. der Schweiz. 29: 512-15.

Murphy, P. A.

1923. On the cause of rolling in potato foliage; and on some further insect carriers of the leafroll disease. Sci. Proc. Roy. Dublin Soc. 17 (n.s.) :20-24; 163-84. 
NatTi, J. J.

1955. Differences in reaction of starch from healthy plants and from potato plants infected with leafroll virus. Phytopathology $45: 185-86$.

Ochs, G.

1959. Ein Virus als Erreger der Rollkrankheit der Rebe. Experientia 15:303.

OLLRAM, F.

1938. Rebenanerkennung-Rollkrankheit. Das Weinland 10:331-32.

Olmo, H. P., and Rizzi, A. D.

1943. Selection for fruit color in the Emperor grape. Proc. Amer. Soc. Hort. Sci. 42:395-400.

OSTERWALDER, A.

1922. Das Auftreten des Rotbrenners in Spätherbst. Landwirt. Jahrb. der Schweiz. 36: $830-31$.

PARMENTIER, G.

1947. Le rougeau de la vigne. Bull. Inst. Agr. et des Sta. Recherches de Gembloux. 16:43-107.

Pastre, J.

1891. La brunissure de la vigne. Progr. agr. et vit. 12:219-33.

PRICE, W. C.

1966. Flexuous rods in the phloem cells of lime plants infected with citrus tristeza virus. Virology $29: 285-94$.

Prilleux, and Delacroix

1895. La brûlure des feuilles de la vigne produite par l' Exobasidium vitis. Compt. Rend.

Prunet, A. Acad. Sci., Paris 119: 106-08.

1894. Sur une Chytridinee parasite de la vigne. Progr. agr. et vit. 15:390-93.

QUANJER, H. M.

1913. Die Nekrose des Phlöems der Kartoffelpflanze, die Ursache der Blattrollkrankheit. Meded. Rijks Hoogere Land-, Tuinen Boschbouwschool. 6:41-76.

1916. Phloemnekrose und Mosaik und die züchterische Massnahmen, wodurch man der Entartung, welche von diesen Kartoffelkrankheiten verursacht wird, in Holland vor-

Ravaz, L. beught. Jahresber. Verein. Angew. Bot. 14:128-45.

1902. Sur la cause de la brunissure. Progr. agr. et. vit. 38:481-86.

1904. Brunissure de la Vigne. Coulet et Fils, Libraires-Editeurs, Montpellier. $186 \mathrm{pp}$.

1925. Flavescence et rougeau. Progr. agr. et vit. 84:461-63.

Ravaz, L., Dupont, E., and Calladaux, R.

1933. Recherches sur le rougeau de la vigne. Ann. P. Agron. N.S. 3:225-31.

Ravaz, L., and Roos, L.

1905. Le rougeot de la vigne. Progr. agr. et vit. 44:363-70; 392-98.

RAVAZ, L., and SiCARD, L.

1903. Sur la brunissure de la vigne. Compt. Rend. Acad. Sci., Paris 136:1276-78.

RAvaz, L., and Verge, G.

1924. Le rougeau de la vigne. Progr. agr. et vit. 81:11-17; 35-38; 86-89; 110-13; 135-41.

ScheU, G.

1936. Mein Winzerbuch. Reichnahrstand. Verlags-Ges. m.b.H. Berlin. 274 pp.

SCHNEIDER, H.

1945. Anatomy of buckskin-diseased peach and cherry. Phytopathology 35:610-35.

1954. Anatomy of bark, bud union, trunk, and roots of quick-decline-affected orange trees on sour orange rootstock. Hilgardia $22(16): 567-81$.

1959. Anatomy of the bud-union of pear trees affected by decline. Phytopathology 49:550. (Abstr.)

Shalla, T. A., Carroll, T. W., and Chiarappa, L.

1964. Transmission of pear decline by grafting. Calif. Agr. 18:4-5.

SHEFFIELD, F. M. L.

1943. Value of phloem necrosis in the diagnosis of potato leafroll. Ann. Appl. Biol. 30:131-36.

SolBerg, R. A., and BALD, J. G.

1962. Virus invasion and multiplication during leaf histogenesis. Virology 17:359-61.

SoURSAC, L.

1924. Le rougeau et le sécheresse. Progr. agr. et vit. 81:116-18.

StellwaAG, F.

1949. Schädlingsbekämpfung im Weinbau. Eugen Elmer in Stuttgart. 112 pp.

StellwhaG, F., and Branas, J.

1938. Des phénomènes de dégénérescence de la vigne. Progr. agr. et vit. 110:413-16. 
TerRier, C., and Staehelin, $M$.

1953. La brunissure de la vigne. Rev. Romande Agr. 9:88-90.

VIALA, P.

1895. La brunissure: recherches nouvelles de MM. U. Brizi et F. Debray. Rev. de viticult. 1895:471.

Viala, P., and Sauvageau, C.

1892. Sur la brunissure, maladie de la vigne causeé par le Plasmodiophora vitis. Compt. Rend. Acad. Sci., Paris 114:1558-60.

VIDAL, J. L.

1943. Les Maladies de la Vigne. Paris: Ancienne Maison Delarue. (Guy le Prat, Editeur). $123 \mathrm{pp}$.

Vuittenez, A.

1958. Transmission par greffage d'une virose du type "enroulement foliare" commune dans les vignobles de l'est et du centre est de la France. Compt. Rend. Acad. Agr. de France $44: 313-16$.

Whitehead, T., McIntosh, T. P., and Findlay, W.

1953. The Potato in Health and Disease. (3rd ed.) Edinburgh: Oliver and Boyd. 744 pp.

WILHELM, A. F.

1938. Die Ursache des vorzeitigen Laubsterbens bei Reben. Der Deut. Weinbau 17:661-63.

1950: Zur Kenntnis von Kalimangelerscheinungen bei der Weinrebe. Phytopathol. Ztschr. 17:240-65.

Woods, A. F.

1899. Brunissure of the vine and other plants. Science 9:508-10.

ZACHAREWICZ, E.

1900. Traitement à essayer contre la brunissure. Progr. agr. et vit. 34:637-38.

1929. La brunissure de la vigne. Compt. Rend. Acad. Agr. de France 15:949-50. 
The journal HILGARDIA is published at irregular intervals, in volumes of about 650 to 700 pages. The number of issues per volume varies.

Single copies of any issue may be obtained free, as long as the supply lasts; please request by volume and issue number from:

\author{
Agricultural Publications \\ University Hall \\ University of California \\ Berkeley, California $\mathbf{9 4 7 2 0}$
}

The limit to nonresidents of California is 10 separate titles. The limit to California residents is 20 separate titles.

The journal will be sent regularly to libraries, schools, or institutions in one of the following ways:

1. In exchange for similar published material on research.

2. As a gift to qualified repository libraries only.

3. On a subseription basis $-\$ 7.50$ a year paid in advance. All subseriptions will be started with the first number issued during a calendar year. Subseribers starting during any given year will be sent back numbers to the first of that year and will be billed for the ensuing year the following January. Make checks or money orders payable to The Regents of The University of California; send payment with order to Agricultural Publications at above address. 